\title{
ФИЗИОЛОГО-БИОХИМИЧЕСКИЕ ЭФФЕКТЫ ДВУХ КОРМОВЫХ АНТИОКСИДАНТОВ ПРИ МОДЕЛИРОВАНИИ ТЕХНОЛОГИЧЕСКОГО СТРЕССА У СВИНЕЙ (Sus scrofa domesticus Erxleben, 1777)*
}

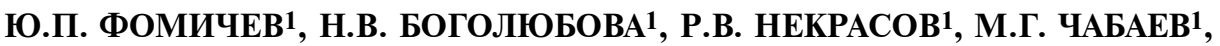 \\ P.A. РЫКОВ 2 , A.A. СЕMEHOBA ${ }^{2}$
}

\begin{abstract}
Условия интенсивного животноводства во многом не соответствуют физиологии сельскохозяйственных видов, сложившейся в процессе эволюции, что наиболее негативно сказывается на высокопродуктивных особях с напряженным обменом веществ. Одно из решений проблемы - использование кормовых антиоксидантов для улучшения продуктивного здоровья, повышения адаптационных возможностей и стрессоустойчивости поголовья. Эффективность применения таких адаптогенов зависит от того, насколько детально изучены механизмы их воздействия на физиолого-биохимические процессы в организме. Мы сравнили эффекты антиоксидантных корригирующих препаратов при моделировании одного из самых распространенных технологических стрессов социального на 36 помесных боровках F2 (крупная белая $\times$ ландрас) $\times$ дюрок (масса в начале опыта 35 кг), из которых сформировали 4 группы по 9 особей: I группа - контрольная без модельного стресса (MC), II - контрольная с МС без коррекции, III и IV группы - МС с коррекцией адаптогенами (соответственно протеинат $\mathrm{Se}-$ ПSе и дигидрокверцетин - ДКВ; 0,2 и 32 мг по д.в. на 1 кг корма). Кровь для исследований брали в начале, середине и в конце эксперимента у 5 особей из каждой группы. Установлено, что с возрастом содержание кортизола в сыворотке крови всех свиней по группам снижалось на 36,$8 ; 22,5 ; 41,3$ и 52,8 \% относительно исходных значений, повышаясь к завершению откорма соответственно на 46,$4 ; 37,4 ; 8,1$ и $60,4 \%$. Наибольшую концентрацию кортизола наблюдали в III группе (с ПSе) в период интенсивного роста (282 нмоль/л против 211 и 214 нмоль/л в I и II контрольных группах), к концу откорма в первых трех группах показатель составил 309, 294 и 305 нмоль/л, а наименышим он был в IV группе (с ДКВ) - 134 нмоль/л (р = 0,07 по сравнению со II контрольной группой) в период интенсивного роста и 215 нмоль/л при заключительном откорме, что корреспондируется с данными по ТБК АП (активные продукты, реагирующие с тиобарбитуровой кислотой), которых тоже было меньше соответственно на 6,7 и 12,3\%. В I группе активность ЛДГ в течение опыта снижалась с 459,4 до 377,5 ед/л, то же отмечали в IV группе (с ДКВ). Во II и III (ПSе) группах к концу откорма показатель по ЛДГ снизился до 317,0 и 289,3 ед/л и стал меньше, чем в I группе, на 16,0 $($ p $<0,01)$ и 23,4 (р < 0,01) \%. В IV группе он тоже постоянно снижался и оставался на 15,$0 ; 7,0$ (p = 0,06 при сравнение со II группой) и $2,7 \%$ ниже, чем в I, II и III группах. МС во II группе снижал концентрацию глюкозы на 13,8 \% относительно I (p < 0,05) при заключительном откорме, в III - также был ниже на $7,4 \%(p<0,05)$, но под влиянием ПSе превышал на $7,4 \%$ таковой во II группе. ДКВ в рационе нивелировал отрицательные эффекты МС, что в сочетании с низким уровнем кортизола стабилизировало концентрацию глюкозы в пределах контроля без МС (I группа). ДКВ также способствовал повышению концентрации триглицеридов в период заключительного откорма - на $25 \%$ (р < 0,01) по сравнению с I группой (без стресса). МС способствовал мобилизации клеточного иммунитета: в конце опыта фагоцитарная активность $(\Phi А)(p<0,05)$, фагоцитарный индекс (ФИ) $($ р $<0,001)$, фагоцитарное число $(Ф Ч)(p<0,05)$ повышались у животных из II группы (МС без коррекции). Применение адаптогенов ПSе и ДКВ нормализовало эти показатели относительно II группы и практически до значений без МС (ФИ при р $<0,01$, ФЧ при р $<0,01$ в первом и р $<0,05$ - во втором случае). Таким образом, под действием адаптогенов показатели резистентности в конце опыта соответствовали отмеченным в I группе, а ДКВ дополнительно повышал гуморальный иммунитет по сравнению с I группой $(\mathrm{p}<0,05)$. Отметим, что на фоне отсутствия существенных различий $(p>0,05)$ по большинству изученных биохимических показателей (что свидетельствует о сбалансированности рационов) выделялись изменения, характеризующие воздействие используемых адаптогенов при МC. Во II-IV группах содержание фосфора в крови было выше, чем в I: 4,42 (p= 0,07), 4,52 (p=0,1) и 4,64 ммоль/л $($ р < 0,05) против 3,94 ммоль/л. Значительно менялось соотношение Са/P: во II (MC), III (MC + ПSе) и IV (MC + ДКВ) группах оно было ниже и составило $1,01(\mathrm{p}<0,05), 0,99(\mathrm{p}<0,05)$ и $0,89(\mathrm{p}<0,001)$ против 1,15 в I группе (без МС и адаптогенов). Число лейкоцитов крови во II, III и IV группах было выше, чем в I группе: в середине откорма - на 12,$5 ; 5,4$ и 6,1 \%, при заключительном откорме - на 32,5 $(\mathrm{p}<0,05) ; 40,1(\mathrm{p}<0,05)$ и $21,7 \%(\mathrm{p}=0,07)$. Характерным было динамическое снижение численности эритроцитов и повышение содержания гемоглобина во всех группах: эти два показателя к завершению откорма в группах с МС были выше, чем в I (на 6,6; 14,3; 9,7 \% и на 1,09; 6,09 и $4,27 \%)$. Также отметим рост содержания эритроцитов $($ p $<0,05)$, гемоглобина $($ p $<0,05)$ и
\end{abstract}

* Исследования проведены при финансовой поддержке РНФ по проекту № 19-16-00068. 
повышение гематокрита (p < 0,01$)$ в III группе (ПSe) по сравнению со II, что свидетельствует о важной роли Se как антиоксиданта. Наблюдаемые изменения были связаны как с действием кортизола в условиях физиологического стресса, так и с повышением неспецифической резистентности животных под влиянием адаптогенов. Среднесуточный прирост массы в опыте был близок к генетически возможному для генотипа F2 (крупная белая $\times$ ландрас) $\times$ дюрок: в среднем по группам 1047, 1035, 1003 и 1042 г (наиболыший - в отсутствие МС и при коррекции ДКВ). Выявленные нами эффекты указывают на перспективность применения ПSе и ДКВ в интенсивном свиноводстве, поэтому необходимо продолжить изучение механизмов действия этих кормовых адаптогенов.

Ключевые слова: стресс, свиньи, адаптогены, антиоксиданты, дигидрокверцетин, селен, кортизол, лактатдегидрогеназа, гематологические показатели, креатинфосфокиназа, ТБК-активные продукты, неспецифическая резистентность.

Интенсивные промышленные технологии содержания поголовья предполагают наличие многочисленных условий, не отвечающих эволюционно обусловленной физиологии сельскохозяйственных животных (1). Современные приоритеты селекции - получение особей с генетически обусловленной высокой продуктивностью. Однако у таких животных реализация продуктивного потенциала создает дополнительные физиологические нагрузки на организм. Это приводит к усугублению влияния стресс-факторов и сопровождается значительными сдвигами в гомеостазе, существенным образом влияя на качество конечной продукции (2).

Стресс - это совокупность неспецифических адаптационных (нормальных) реакций организма на воздействие различных неблагоприятных факторов (стрессоров), нарушаюшее его гомеостаз, а также соответствующее состояние нервной системы или организма в целом. Ганс Селье (Hans Sely, 1907-1982) впервые ввел понятие стресса как неспецифической реакции организма на любое изменение (3). В животноводстве в зависимости от причины стресс классифицируют как социальный (технологический), экологический, диетарный, иммунологический (4). Социальный (или технологический) стресс возникает при распределении по клеткам с незнакомыми особями, изоляции, при отъеме, транспортировке, проведении ветеринарных мероприятий и т.д. Подверженность социальному стрессу носит всегда индивидуальный характер и зачастую связана с генетическими факторами, что подтверждено многими исследованиями (5). Социальный стресс может быть острым (моментальным после перегруппировки) или хроническим, когда животные содержатся в групповых клетках или изолированно, а также в результате повторных перегруппировок (6). Показано, что частота социальных взаимодействий и агрессивного поведения животных возрастает по мере повышения плотности содержания $(7,8)$, а интенсивность роста положительно коррелирует с площадью станка в расчете на одно животное (9). Известно также, что реакция на социальный стресс зависит от пола, и у самцов она выше, чем у самок $(10,11)$. К критическим этапам в технологии выращивания свиней относится период отъема и перевод на доращивание. Лишение материнского присутствия и молока, перевод в новое помещение, перегруппировка, смена кормов и обслуживающего персонала вызывают у поросят технологический стресс, как следствие, повышается заболеваемость, замедляется темп роста. При этом снижается естественная резистентность и показатели гуморального иммунитета, создаются условия для активации условно-патогенной микрофлоры, что приводит к расстройству пищеварения или респираторной патологии (12). При хроническом воздействии различных стрессовых ситуаций активируется свободнорадикальное окисления при одновременном истощении звеньев антиоксидантной защиты. В организме формируются синдромы стрессовой дезадаптации, кетоза, гепатодистофии, происходят аутоиммунные процессы (13).

Для стабилизации уровня свободных радикалов, снижения воздей- 
ствия стрессовых факторов среды и повышения адаптационной способности организма в рационы вводят субстраты с антиокислительной активностью (14). К веществам с подобными свойствами относятся биофлавоноид дигидрокверцетин и эссенциальный микроэлемент селен. Дигидрокверцетин, который получают из лиственницы Даурской (Larix dahurica Turez), обладает широким спектром биологических свойств: регулирует метаболические процессы, положительно влияет на функции органов и систем организма (в частности, на сердечно-сосудистую систему), участвует в защите здоровых клеток организма от патологических изменений посредством нейтрализации радикальной активности. Селен также относится к сильным антиоксидантам, профилактирует сердечно-сосудистые заболевания, обладает иммуномодулирующим действием в отношении клеточного и гуморального звеньев иммунитета. Sе обнаружен во многих функционально активных белках - селенопротеинах, к которым, в частности, относятся глутатионпероксидазы и тиреодоксинредуктазы. Кроме того, он предупреждает у животных алиментарную мышечную дистрофию.

Следует отметить, что в последние годы изучению фитосырья уделяется особое внимание, так как многие растения, в том числе овощи и пряности, содержат антиоксиданты $(15,16)$, в том числе флавоноиды и фенольные компоненты $(17,18)$. Флавоноиды - вторичные метаболиты растений, проявляющие спектр фармакологических и биологических свойств $(19,20)$. Дигидрокверцетин $\left(\mathrm{C}_{15} \mathrm{H}_{12} \mathrm{O}_{7}\right)$ (ДКВ) - доминирующий компонент биофлавоноидного комплекса диквертина. Использование дигидрокверцетина в рационе свиней блокировало процессы перекисного окисления липидов в течение всего периода выращивания и откорма (21). Включение в рацион поросят в послеотъемный период кормовой добавки с ДКВ (Экостимул-2, Россия, по 50 мг гол. $^{-1} \cdot$ сут $^{-1}$ ) значительно ослабляло действие стрессовых факторов среды и повышало адаптационную способность животных, в результате среднесуточный прирост в период после отъема составил 496 г, что было на 20,6 \% выше, чем у контрольных особей (22). ДКВ в качестве добавки при кормлении свиней блокировал свободнорадикальное окисление липидов, усиливал антиоксидантную защиту организма и улучшал функциональное состояние печени в течение всего периода выращивания и откорма. В другом эксперименте кверцетин ослаблял оксидативный стресс и уменьшал воспаление кишечника, при этом снижалось количество активных форм кислорода (АФК) и малонового диальдегида (МДА) в кишечнике, эндотоксина - в сыворотке крови, увеличивалась высота ворсинок тощей кишки (23). Синтезированы серии новых 3-моноацилированных производных дигидрокверцетина, обладающие усиленными антиоксидантными свойствами (24).

Таким образом, для разработки способов улучшения продуктивного здоровья и повышения стрессоустойчивости животных в условиях промышленного свиноводства требуется углубленное понимание механизмов воздействия алиментарных антиоксидантов на физиолого-биохимические процессы в организме.

В настоящей работе нами представлены результаты изучения комплекса показателей метаболического, гормонального, антиоксидантного статуса и резистентности у свиней, получавших антиоксидантные корригирующие препараты, при моделировании социального стресса как одного из самых распространенных технологических стрессов. Обсуждается возможность их использования для нивелирования воздействия модельного стрессора.

Нашей целью было сравнение физиолого-биохимических показателей, характеризующих продуктивный и адаптивный статус, у свиней, полу- 
чавших антиоксидантные препараты на основе дигидрокверцетина и селена в условиях модельного технологического стресса.

Методика. Исследования проводили в 2019 году на 36 помесных боровках (Sus scrofa domesticus) F2 (крупная белая $\times$ ландрас) $\times$ дюрок с живой массой в начале опыта 35 кг в возрасте 103 сут после периода доращивания (экспериментальный двор ФНЦ ВИЖ им. Л.К. Эрнста). По принципу аналогов были сформированы 4 группы (по $n=9)$ : I контрольная; II контрольная, подвергавшаяся моделируемому стрессу (MC); в III и IV животные в условиях МС на протяжении всего опытного периода получали с кормом соответственно селен (Se) в форме протеината (ПSe) (B-TRAXIM Selenium-11, «PANCOSMA CANADA, Inc.», Канада) и дигидрокверцетин (ДКВ) в форме кормовой добавки Экостимул-2 (экстракт из лиственницы Даурской, содержащий 80 \% дигидрокверцетина и 20 \% других антиоксидантов) (ООО «Аметис», Россия). Основу рациона составляли комбикорма СК-5 и СК-6 (ООО «Агровитекс», Россия), сбалансированные по питательным веществам и энергии согласно современным нормам (25). Дозы добавок (по д.в.) - 0,2 мг ПSе и 32 мг ДКВ на 1 кг корма согласно схеме опыта. Для моделирования социального стресса животных переместили из одного станка в другой в пределах группы в начале опыта и далее повторяли перемещения через каждые 14 сут таким образом, чтобы после перестановки в станке оказывались ранее не находившиеся вместе животные. Для оценки клинико-физиологического и метаболического статуса у животных (по 5 особей из каждой группы) пункцией яремной вены отбирали образцы крови перед началом опыта, перед заключительным откормом и перед убоем. Биохимические показатели сыворотки крови определяли на автоматическом биохимическом анализаторе Chem Well («Awareness Technology», США), морфо-гематологические показатели - на гематологическом анализаторе ABC VET («HORIBA ABX Diagnostics Inc.», Франция), кортизол - иммуноферментным методом, ТБК (тиобарбитуровая кислота)активные продукты - с помощью биохимического набора (ООО «АгатМед», Россия), общее количество водорастворимых антиоксидантов (BА) на приборе Цвет-Яуза-01-АА (ОАО НПО «ХИМАВТОМАТИКА», Россия), активность лактатдегидрогеназы (ЛДГ) и креатинфосфокиназы (КФК) - с помощью биохимического анализатора Bio Chem FC-360 («HT»I, CША). Неспецифическую резистентность изучали по бактерицидной активности сыворотки крови (БАСК) фотонефелометрическим методом, лизоцимную активность сыворотки крови (ЛАСК) - по методу В.И. Мутовина, фагоцитарную активность (ФА) - по поглощающей и переваривающей способности клеток крови.

Полученные данные обрабатывали биометрически методом дисперсионного анализа (ANOVA) в программе STATISTICA 10 («StatSoft, Inc.», США). Вычисляли среднеарифметические значения $(M)$, среднеквадратическую ошибку $( \pm \mathrm{SEM})$ и уровень значимости (p; различия считали статистически значимыми при $\mathrm{p}<0,05)$. Сравнение проводили с контрольными группами I (без МC) и II (с MC).

Результаты. Социальный стресс (перенапряжение, связанное с необходимостью социальной адаптации, приспосабливания, взаимодействия в сообществе) очень часто возникает в производственных условиях при выращивании свиней. В нашем опыте у животных I контрольной группы, которых содержали без смены станков в течении всего периода опыта, случаи агрессивного поведения были единичными. Создание стресса для животных II контрольной, III и IV опытной группы при периодическом обновлении соседствующих особей в станках вызывало более беспокойное и агрессивное 
поведение. Животные из II, III и IV группы были более активны при движении, часто взаимодействовали друг с другом. Число случаев агрессивного поведения прямо зависело от процента беспокойных животных в группе (рис. 1).

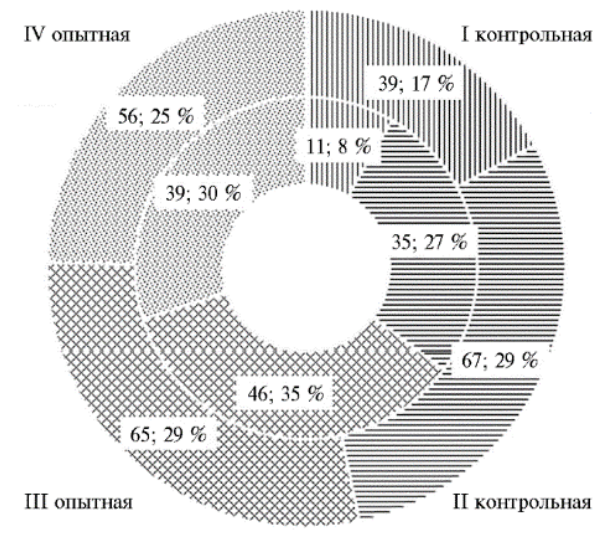

Рис. 1. Соотношение частоты случаев агрессивного поведения (\%) и доли беспокойных животных (\%) по группам свиней (Sus scrofa domesticus) F2 (крупная белая $\times$ ландрас) $\times$ дюрок за период испытаний. Внешний круг - число случаев агрессивного поведения (абсолютное значение за период наблюдений и процент от общего числа случаев); внутренний круг - число беспокойных животных (абсолютное значение за период наблюдений и процент от общего числа случаев) (экспериментальный двор ФНЦ ВИЖ им. Л.К. Эрнста, 2019 год, $N=36, n=9$ ).

Действие МС фиксировали по актам агрессивного поведения, которое особенно отчетливо проявлялось в первые 2-3 сут после перестановки животных. Каждый раз этот период характеризовался выстраиванием иерархической структуры, снижением потребления кормов, укусами и повышенным травматизмом, беспокойством, особенно во II и III группах. Так, число случаев агрессивного поведения было минимальным в контроле - 39 случаев, среди животных II, III и IV групп - соответственно 65, 67 и 56 случаев, или 29, 29 и $25 \%$ от их общего числа за период опыта. В группе животных, подвергавшихся воздействию МС, но получавшие в составе рациона ДКВ, отмечали снижение числа актов агрессивного поведения особей при том же числе выявленных случаев беспокойства в период действия МС.

Важно отметить, что продуктивность свиней (среднесуточный прирост массы) была близка к генетически возможной для генотипа F2 (крупная белая $\times$ ландрас) $\times$ дюрок. В результате за весь период исследования получили прирост в среднем 1047, 1035, 1003 и 1042 г соответственно в I, II, III и IV группах, то есть наибольшим он был в I контрольной (без стресса) и в IV (MC + ДКВ) группах.

Изучение белкового, азотистого, углеводно-липидного и минерального обмена у свиней в связи с их ростом и действием МС на фоне применения ПSе и ДКВ показало значительные различия и изменения в метаболизме как между группами свиней, так и по периодам откорма. Содержание общего белка и его фракций в сыворотке крови характеризует интенсивность и направленность белкового обмена и тесно связано с ростом, влиянием факторов среды и составом рациона (26). У свиней всех групп перед постановкой на откорм содержание общего белка в сыворотке крови колебалось от 65,8 до 73,1 г/л, находясь в пределах физиологической нормы, равной 55-82 г/л. То же наблюдалось и по содержания альбуминов (А) и глобулинов (Г) - соответственно 36,7-38,7 и 29,1-43,4 г/л при физиологической норме 19-43 и 26-57 г/л. При этом соотношение А/Г было выше среднего референтного значения, что указывало на интенсивный анаболизм в организме (табл. 1). В течение эксперимента наблюдалась общая закономерность в изменении концентрации общего белка и его фракций в сыворотке крови у свиней всех групп, а именно рост показателя в период интенсивного роста за счет альбуминовой фракции и уменьшение к концу откорма за счет глобулиновой фракции. В результате соотношение А/Г 
повышалось в течение всего периода наблюдения, что мы оцениваем как положительный факт. Тем не менее при этом имели место различия между группами. Так, в опытный период у II контрольной группы под влиянием МС за счет альбуминовой фракции содержание общего белка было на 3,5 \% ниже $(\mathrm{p}<0,05)$, чем у свиней из I контрольной группы, при равном содержании глобулинов, что могло свидетельствовать об усиленном использовании пластических веществ на энергетические нужды организма. В период заключительного откорма у свиней этой группы содержание общего белка в сыворотке крови сохранялось на уровне контроля. В эксперименте воздействие адаптогенов на белковый обмен было положительным и определялось их биологической активностью. Так, на фоне MC адаптогены ПSe и ДКВ подавляли катаболические процессы и усиливали анаболические в период интенсивного роста свиней, в результате чего содержание общего белка и его фракций в сыворотке крови сохранялось таким же, как в I контрольной группе. В заключительный период откорма лучшие показатели белкового обмена были в IV группе свиней, получавших ДКВ. В их сыворотке крови содержание альбуминов составило 44,4 г/л при А/Г $=1,78$, в то время как эти показатели у свиней I, II контрольных групп и III опытной составили соответственно 41,9; 42,4 и 41,8 г/л при отношении А/Г 1,70; 1,55 и 1,64, то есть наименьшей эта величина была во II контрольной группе под влиянием МС (табл. 1).

1. Основные показатели обменных процессов у свиней (Sus scrofa domesticus) $\mathrm{F}_{2}$ (крупная белая $\times$ ландрас) $\times$ дюрок в период откорма $(n=5, M \pm \mathrm{SEM}$, ФНЦ ВИЖ им. Л.К. Эрнста, 2019 год)

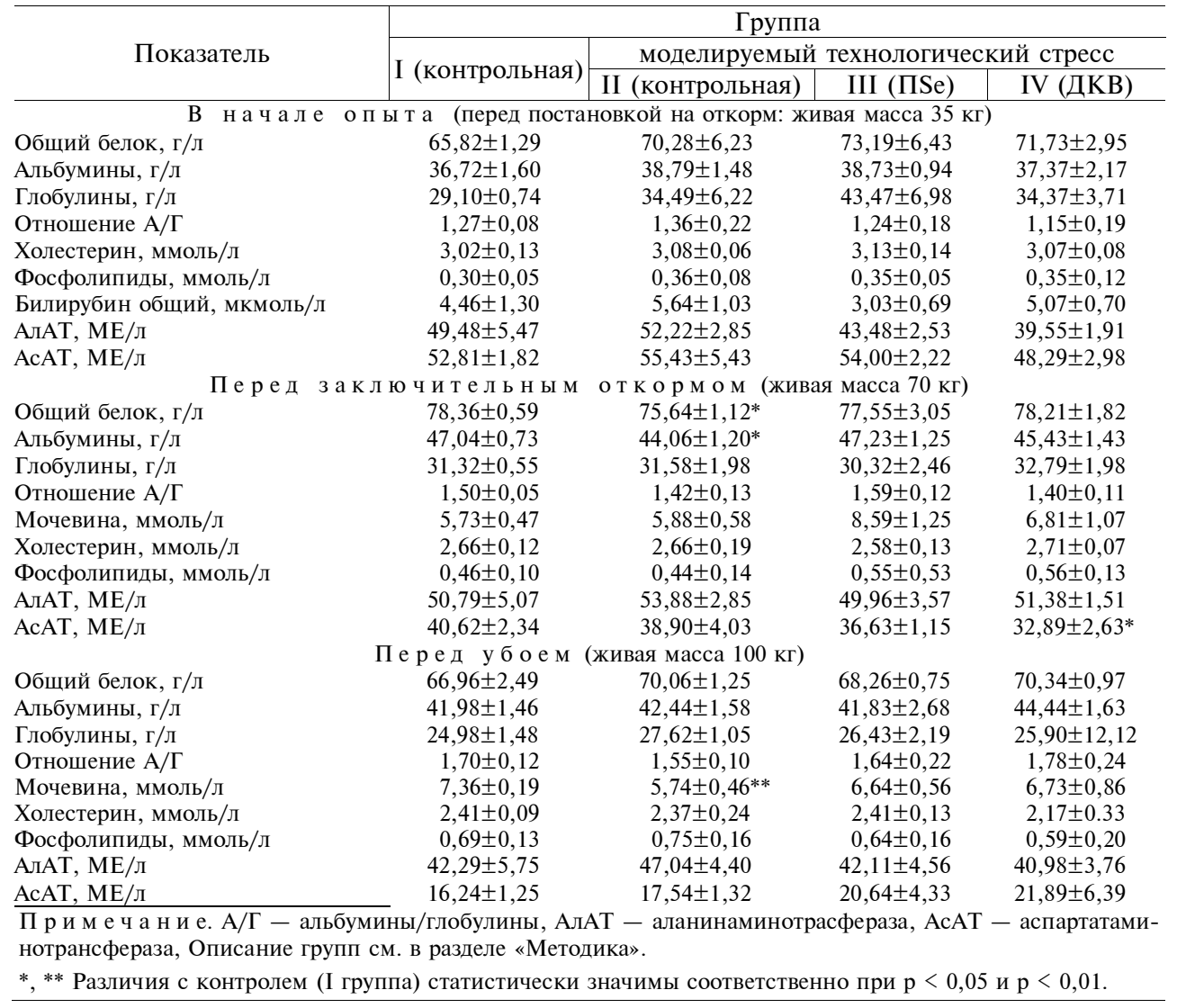

В условиях эксперимента у свиней всех групп концентрация 
мочевины в сыворотке крови была в пределах физиологической нормы (3,5-9,2 ммоль/л). Во время интенсивного роста ее содержание в сыворотке крови животных из контрольных групп было одинаковым, на стадии заключительного откорма - повысилось на 28,4 \% в I контрольной группе, но не изменилось во II контрольной (соответственно 5,88 и 5,74 ммоль/л). Следует подчеркнуть, что концентрация мочевины в группах с МС была ниже контрольных значений без МС, и во II контрольной группе мы зафиксировали ее достоверное снижение $(\mathrm{p}<0,01)$. Повышение содержания мочевины в сыворотке крови при нормальной мочевинообразовательной функции печени могло быть связано со снижением интенсивности обновления белков в тканях и анаболическими процессами. Наблюдаемый в этой связи эффект адаптогенов при МС был следующим. Содержание мочевины у свиней из III (ПSe) и IV (ДКВ) групп было выше, чем в I контрольной (без стресса), соответственно на 49,9 и 18,8 \%, чем во II (MC) - на 46,0 и 15,5\%. В заключительный период откорма этот показатель в группах, получавших адаптогены, снизился на 22,8 и на $1,2 \%$, в результате чего он сравнялся и составил 6,64 и 6,73 ммоль/л, в то время, как в I и II контрольных группах его величина равнялась 7,36 и 5,74 ммоль/л (см. табл. 1). Статистически значимых различий со II группой (контроль с МС) при анализе данных мы не выявили.

В жизнедеятельности организма, особенно в условиях физиологического стресса, важную роль играют липиды - холестерин, фосфолипиды и триглицериды, которые входят в состав клеточных мембран. Содержание холестерина в сыворотке крови свиней всех групп было практически равным и колебалось в пределах 2,17-3,13 ммоль/л. При этом наблюдалась закономерность в снижении показателя к концу периода откорма на 10,1; 13,$1 ; 13,1$ и 29,4 \% по группам. Достоверных различий с контрольными группами не отмечали, что указывает на стабильность этого показателя при воздействии МС. Концентрация фосфолипидов в сыворотке крови варьировала в пределах 0,30-0,75 ммоль/л и повышалась к концу заключительного откорма. При этом повышение содержания фосфолипидов наблюдали в период интенсивного роста в группах с адаптогенами (соответственно 0,55 и 0,56 ммоль/л против 0,46 и 0,44 ммоль/л в I и II группах). К концу заключительного откорма соотношение изменилось из-за более значительного повышения показателя в контрольных группах (соответственно до 0,69 и 0,75 ммоль/л против 0,64 и 0,59 ммоль/л в группах с адаптогенами) (см. табл. 1). В целом анализ содержания липидов в сыворотке крови и изменений их концентраций в период опыта выявил влияние МС на энергетический обмен и его коррекцию адаптогенами. При чем более эффективным было действие ДКВ.

В течение опыта активность АлАТ и АсАТ в сыворотке крови во всех группах находилась в пределах физиологической нормы (по АлАТ и АсАТ соответственно 22-98 и 19-96 МЕ/л). Активность указанных ферментов варьировала в пределах соответственно 39,55-53,88 и 16,2-55,43 МЕ/л. При этом наблюдался некоторый рост активности АлАТ в период интенсивного роста и снижение - к концу заключительного откорма. Изменение активности АсАТ было более значительным и имело иной характер (постоянное снижением в течение опыта, в итоге по группам соответственно на 69,3, $68,3,52,6$ и 44,7 \% к концу опыта), что могло характеризовать уменышение интенсивности белкового обмена и использования аминокислот на энергетические цели (см. табл. 1). Более плавное изменение отмечали в IV 
висели от МС и действия адаптогенов, хотя и не превышали физиологическую норму - 2,3-4,9 ммоль/л. Так, при интенсивном росте показатель по фосфору повышался на 17,$2 ; 38,1 ; 49,6$ и 55,1 \%, к завершению финального откорма - снижался на 22,$4 ; 30,1 ; 31,2$ и $29,8 \%$ относительно периода интенсивного роста, в результате чего концентрация фосфора в сыворотке крови по группам практически сравнялась $(3,06 ; 3,09 ; 3,11$ и 3,26 ммоль/л) (см. табл. 2). Изменения в содержании фосфора значительно влияло на соотношение $\mathrm{Ca} / \mathrm{P}$. Так, во время интенсивного роста величина $\mathrm{Ca} / \mathrm{P}$ в контрольных группах снизилась на 21,3 и 25,2 \%, в группах с адаптогенами на 30,8 и 41,5\%. К концу финишного откорма она практически сравнялась во всех группах (соответственно 1,26; 1,26; 1,23 и 1,17). Вариабельность содержания фосфора в крови на разных стадиях откорма мы объясняем его участием в энергетическом обмене. В частности, при МС в время интенсивного роста во II-IV группах содержание фосфора в крови было выше, чем в I контрольной группе, $-4,42(\mathrm{p}=0,07), 4,52(\mathrm{p}=0,1)$ и 4,64 ммоль/л $(\mathrm{p}<0,05)$ против 3,94 ммоль/л. В связи с этим значительно изменялось соотношение $\mathrm{Ca} / \mathrm{P}$ в середине откорма. Во II контрольной и опытных группах (ПSе и ДКВ) его величина была ниже и составила 1,01 (p < 0,05), 0,99 $(\mathrm{p}<0,05)$ и $0,89(\mathrm{p}<0,001)$ против 1,15 в контроле (I группа).

Физиологическая норма для магния у свиней равна 0,9-1,7 ммоль/л. В наших исследованиях концентрация магния в сыворотке крови не различалась по группам, снижаясь в период интенсивного роста к концу заключительного откорма. В начале и конце опыта этот показатель был в пределах референтных значений (см. табл. 2). На этом фоне в группах с МС в середине откорма его значения были выше контрольных значений $(\mathrm{p}<0,05)$.

Содержание железа в сыворотке крови свиней I контрольной группы в течение всего опыта было стабильным и составляло 25,10-25,27 мкмоль/л. Во II контрольной группе в условиях МС в период интенсивного роста оно повысилось с 21,5 до 28,49 мкмоль/л и сохранялось до конца откорма. В III и IV группах этот показатель также повышался в период интенсивного роста, но к концу откорма в III группе он снизился до первоначального значения, а в IV (с ДКВ на фоне MC) - продолжал расти до величины во II контрольной группы (в III и IV группах соответственно 28,5 и 28,4 мкмоль/л) (см. табл. 2). Концентрация хлоридов в сыворотке крови в течение всего опыта была близкой во всех группах, повышаясь в период интенсивного роста на 22,9-25,7 \% и снизившись к концу откорма снизилось на 6,47,0 \% в контрольных группах и на 11,21-11,3\% в группах с адаптогенами (см. табл. 2).

Кортизол - гормон стресса, который защищает организм от резких колебаний физиологического равновесия (29). Под влиянием этого гормона усиливается протеолиз с последующим образованием из продуктов распада белка углеводов (30). Система антиоксидантной защиты организма предназначена для поддержания баланса БАС (биологически активных соединений: липидов, пептидов, витаминов и других соединений) в органах и тканях организма животных, защищая их от АФК (31).

Установлено, что под влиянием МС и используемых адаптогенов содержание кортизола, ТБК-АП и суммы водорастворимых антиоксидантов (ВА) в крови животных достоверно не различалось во все сроки опыта. Тем не менее в наших исследованиях было отмечено, что в период интенсивного роста содержание кортизола крови свиней с возрастом снижалось соответственно на 36,$8 ; 22,5 ; 41,3$ и $52,8 \%$ относительно исходных значений, а к концу заключительного откорма повышалось (на 46,4; 37,4; 8,1 и 60,4 \%). При этом наименьшие значения -134 нмоль/л ( $=0,07$ по сравнению со 
II группой) при интенсивном росте и 215 нмоль/л в период заключительного откорма отмечали у свиней из IV группы. Наибольшее значение выявили у свиней в группе с ПSе в период интенсивного роста (282 нмоль/л против 211 и 214 нмоль/л в I и II контрольных группах). К концу откорма в I-III группах концетрация кортизола сравнялась и составила 309, 294 и 305 нмоль/л. Таким образом, при МС перед заключительным откормом уровень кортизола в крови свиней, получавших ДКВ, был минимальным по сравнению с другими группами и на 37,3 и 47,5 \% ниже, чем во II (MC) и III (MC + ПSe), группах что корреспондируется с данными по ТБК АП, которых также было меныше соответственно на 6,7 и 12,3 \% (табл. 3).

3. Содержание кортизола в крови и состояние антиоксидантной защиты у свиней (Sus scrofa domesticus) F2 (крупная белая $\times$ ландрас) $\times$ дюрок в период откорма ( $n=5, M \pm \mathrm{SEM}$, ФНЦ ВИЖ им. Л.К. Эрнста, 2019 год)

\begin{tabular}{|c|c|c|c|c|}
\hline \multirow{3}{*}{ Показатель } & \multicolumn{4}{|c|}{ Группа } \\
\hline & \multirow{2}{*}{ I (контрольная) } & \multicolumn{3}{|c|}{ моделируемый технологический стресс } \\
\hline & & II (контрольная) & III (ПSe) & IV (ДКВ) \\
\hline \multicolumn{5}{|c|}{ В н а ч а л е о п ы т а (перед постановкой на откорм: живая масса 35 кг) } \\
\hline Кортизол, нмоль/л & $334 \pm 116$ & $276 \pm 54$ & $480 \pm 48$ & $284 \pm 73$ \\
\hline ТБК-АП, мкмоль/л & $4,18 \pm 0,29$ & $3,67 \pm 0,48$ & $4,10 \pm 0,80$ & $4,45 \pm 0,50$ \\
\hline Сумма ВА, мг/Г & $26,12 \pm 0,67$ & $24,26 \pm 1,10$ & $26,06 \pm 0,97$ & $25,40 \pm 1,11$ \\
\hline \multicolumn{5}{|c|}{ Перед $з$ аключительным } \\
\hline Кортизол, нмоль/л & $211 \pm 65$ & $214 \pm 34$ & $282 \pm 45$ & $134 \pm 26$ \\
\hline ТБК-АП, мкмоль/л & $3,08 \pm 0,21$ & $3,14 \pm 0,14$ & $3,34 \pm 0,45$ & $2,93 \pm 0,54$ \\
\hline Сумма ВА, мг/г & $12,20 \pm 0,64$ & $11,28 \pm 0,88$ & $12,20 \pm 0,90$ & $11,76 \pm 1,00$ \\
\hline \multicolumn{5}{|c|}{ П е ре д у б о е м (живая масса 100 кг) } \\
\hline Кортизол, нмоль/л & $309 \pm 107$ & $294 \pm 111$ & $305 \pm 61$ & $215 \pm 53$ \\
\hline ТБК-АП, мкмоль/л & $3,22 \pm 0,35$ & $3,41 \pm 0,34$ & $3,08 \pm 0,25$ & $3,47 \pm 0,50$ \\
\hline Сумма ВА, мг/г & $12,54 \pm 0,48$ & $12,04 \pm 0,69$ & $13,30 \pm 1,30$ & $12,32 \pm 0,96$ \\
\hline
\end{tabular}

С данными по ТБК-АП (31) согласовывались показатели общего содержания водорастворимых антиоксидантов в сыворотке крови: во все периоды опыта они имели близкие значения во всех группах с заметным уменьшением при действии МС в период интенсивного роста и перед убоем с тенденцией к росту в группах, где свиньи получали адаптогены (см. табл. 3).

Одним из продуктов белкового обмена является креатинин, который образуется в мышечной ткани из креатина (32). Содержание креатинина в крови свиней в течение эксперимента находилось в пределах физиологической нормы (78-148 мкмоль/л) с повышением в период интенсивного роста и снижением к концу откорма. Однако между группами отмечались различия. Во II контрольной группе в условиях МС в период интенсивного роста содержание креатинина повысилось на 17,0 \%, в I контрольной - на $62,8 \%$. В III и IV группах с адаптогенами это повышение занимало промежуточное положение между I и II группами (соответственно на 47,7 и 41,2 \%). В итоге в I, III и IV группах показатель составил 124,2; 122,0 и 122,0 против 108,2 мкмоль/л во II группе (табл. 4), что связано, в том числе, с действием адаптогенов на фоне МС. Перед убоем содержание креатинина имело ту же картину, наименышим его значение было в II группе.

Метаболизм глюкозы на уровне клеток во многом зависит от особенностей гормонального статуса организма. В частности, глюкокортикоиды (кортизол и другие), способствуя образованию углеводов из безазотистых остатков аминокислот угнетают окисление глюкозы, что приводит к увеличению ее содержания в крови (30). Тиреоидные гормоны усиливают всасывание глюкозы из кишечника, что также приводит к ее накоплению в крови (33). Гипергликемический эффект проявляют и гормоны передней доли гипофиза - соматотропин, кортикотропин и тиротропин (34). В 
нашем опыте концентрация глюкозы в сыворотке крови по группам и периодам опыта колебалась в пределах 5,92-9,17 ммоль/л. Проявилась закономерность в снижении этого показателя к концу экспериментов. Более стабильным и устойчивым он был в IV группе (ДКВ). В завершающий период откорма включение адаптогенов в рацион стабилизировало количество глюкозы в крови. МС снижал концентрацию глюкозы на 13,8 \% (p < 0,05) по сравнению с контролем без МС. В ІІІ группе МС снижал этот показатель на 7,4 \% (p < 0,05), но под влиянием ПSе он повышался относительно II группы на те же 7,4 \%. ДКВ в составе рациона нивелировал отрицательное воздействия МС, что на фоне низких показателей по кортизолу в этой группе стабилизировало концентрацию глюкозы в сыворотке крови животных на уровне контроля без МС (см. табл. 4).

4. Динамика изменения активности ферментов крови у свиней (Sus scrofa domesticus) $\mathrm{F}_{2}$ (крупная белая $\times$ ландрас) $\times$ дюрок в период откорма и ее взаимосвязь с показателями углеводно-липидного обмена $(n=5, M \pm \mathrm{SEM}$, ФНЦ ВИЖ им. Л.К. Эрнста, 2019 год)

\begin{tabular}{|c|c|c|c|c|}
\hline \multirow{3}{*}{ Показатель } & \multicolumn{4}{|c|}{ Группа } \\
\hline & \multirow{2}{*}{ I (контрольная) } & \multicolumn{3}{|c|}{ моделируемый технологический стресс } \\
\hline & & II (контрольная) & III (ПSe) & IV (ДКВ) \\
\hline \multicolumn{5}{|c|}{ В н а ч а л е о п ы т а (перед постановкой на откорм: живая масса 35 кг) } \\
\hline Триглицериды, ммоль/л & $0,35 \pm 0,07$ & $0,32 \pm 0,06$ & $0,37 \pm 0,04$ & $0,36 \pm 0,03$ \\
\hline Глюкоза, ммоль/л & $9,17 \pm 1,27$ & $8,47 \pm 0,45$ & $7,07 \pm 0,69$ & $6,49 \pm 0,50$ \\
\hline ЛДГ, ЕД/л & $459,4 \pm 171,4$ & $378,5 \pm 39,8$ & $375,9 \pm 34,3$ & $390,9 \pm 24,0$ \\
\hline КФК, ЕД/л & 2769,2 & $1996,0 \pm 715,5$ & $2656,5 \pm 856,5$ & $2927,5 \pm 1315,2$ \\
\hline нин, мкмоль/л & $76,3 \pm 5,7$ & $92,5 \pm 13,0$ & $82,6 \pm 9,0$ & \\
\hline Перед & лю ч и те ль н ы м & о т к о р м о м (жив & ая масса 70 кг) & \\
\hline Триглицериды, ммоль/л & $0,32 \pm 0,04$ & $0,32 \pm 0,03$ & $0,34 \pm 0,09$ & $0,25 \pm 0,02^{\mathrm{a}}$ \\
\hline Глюкоза, ммоль/л & $8,41 \pm 0,80$ & $7,65 \pm 0,56$ & $7,81 \pm 0,48$ & $7,32 \pm 0,44$ \\
\hline ЛДГ, ЕД/л & $407,5 \pm 22,4$ & $450,9 \pm 28,4$ & $423,9 \pm 25,1$ & $379,2 \pm 24,3$ \\
\hline КФК & 260,9 & $1649,5 \pm 779,4$ & $1591,4 \pm 654,0$ & $\pm 429,2$ \\
\hline \multirow[t]{2}{*}{ Креатинин, мкмоль/л } & $124,2 \pm 8,8$ & $108,2 \pm 6,8$ & $122,0 \pm 10,9$ & $122,0 \pm 8,3$ \\
\hline & $\Pi$ e p e & (живая масса 100 кг) & & \\
\hline ммоль/л & $0,28 \pm 0,03$ & $0,28 \pm 0,01$ & $0,32 \pm 0,04$ & $0,35 \pm 0,05^{* *}$ \\
\hline Глюкоза, ммоль/л & $6,87 \pm 0,70$ & $5,92 \pm 0,32^{*}$ & $6,36 \pm 0,56^{*}$ & $6,48 \pm 0,68$ \\
\hline ЛДГ, ЕД/л & $377,5 \pm 44,3$ & $317,0 \pm 23,8^{* *}$ & $289,3 \pm 34,5^{* *}$ & $367,4 \pm 33,6$ \\
\hline КФК, ЕД/л & $2484,0 \pm 916,6$ & $1796,9 \pm 643,8$ & $1368 \pm 573,5$ & $3229,5 \pm 1261,6$ \\
\hline Креатинин, мкмоль/л & $112,9 \pm 11,9$ & $101,4 \pm 9,1$ & $103,4 \pm 4,5$ & $107,8 \pm 10,7$ \\
\hline \multicolumn{5}{|c|}{$\begin{array}{l}\text { П р и м е ч а н и е. ЛДГ- лактатдегидрогеназа, КФК - креатинфосфокиназа. Описание групп см. в разделе } \\
\text { «Методика». } \\
\text { *, ** Различия с контролем (І группа) статистически значимы соответственно при р }<0,05 \text { и р }<0,01 . \\
\text { а Различия с контролем (II группа) статистически значимы соответственно при } \mathrm{p}<0,05 .\end{array}$} \\
\hline
\end{tabular}

Лактатдегидрогеназа (ЛДГ) - цинксодержащий внутриклеточный фермент, который отвечает за энергетический обмен через катализ окисления молочной кислоты в пируват. ЛДГ содержится практически во всех клетках организма и наиболее активна в скелетной мускулатуре, сердечной мышце, почках, печени и эритроцитах (35). Перед началом опыта активность ЛДГ в крови свиней составила 375,9- 390,9 ME/л во II-IV группах, 459,4 ME/л - в I в контрольной. Далее в I группе она постоянно снижалась (до 407,5 МЕ/л перед заключительным откормом и до 377,5 МЕ/л перед убоем). Во II и III группах активность ЛДГ в условиях МС (перед заключительным откормом) повысилась на 19,1 и 12,8 \%, затем снизилась и составила 317,0 и 289,3 ME/л, что было меньше, чем в I группе соответственно на $16,0(\mathrm{p}<0,01)$ и 23,4 \% (p < 0,01). В IV группе этот показатель по периодам исследования постоянно снижался, как и в I группе, и при этом оставался на 15,0; 7,0 (p = 0,06 при сравнение со II группой) и 2,7 \% ниже, чем в I, II и III группах (см. табл. 4). Активность ЛДГ и ее динамика в сыворотке характеризуют степень физических нагрузок на организм свиней в опыте и влияние антиоксидантов на энергетический обмен в мышцах. Следует 
отметить, что при действии ДКВ активность ЛДГ была такой же, как у животных, не подвергавшихся МС, то есть не происходило ее достоверного изменения под влиянием стресс-фактора.

Креатинфосфат относится к фосфагенам, которые предотвращают быстрое истощение запасов АТФ, поставляя легко используемый макроэргический фосфат, необходимый для ресинтеза АТФ из АДФ. Креатинфосфат образуется из АТФ и креатина при расслаблении мышцы. Фосфорилирование креатина катализирует креатинфосфокиназа (КФК) - фермент, специфичный для мышц (36). У всех групп в начале исследования активность КФК находилась в пределах 1996-2927 ЕД/л. При интенсивном росте показатель по группам снизился на 78,3; 17,4; 40,1 и 65,3 \%. В конце откорма (перед убоем) активность КФК повышалась на 282,9; 8,9 и 316,9 \% соответственно в I, II и IV группах, но в III - снижалась на 14,1 \%. Эти данные отражают изменение расходования энергии в форме макроэргов в разные периоды опыта и влиянии антиоксидантов на эти процессы (см. табл. 4).

Содержание триглицеридов в сыворотке крови свиней варьировало в пределах 0,66-0,95 ммоль/л и повышалось к концу заключительного откорма во всех группах. При этом наименьший прирост концентрации (на $27,1 \%$ ) происходил в I, наибольший (на 42,4 \%) - во II группе. В присутствии адаптогенов прирост составил 30,1 и 30,9 \%, что было близко к показателям в I группе (контроль без МС). Использование ДКВ способствовало повышению содержания триглицеридов на $25 \%$ ( $<<0,01)$ по сравнению с контрольной группой без стресса.

Неблагоприятные факторы среды непосредственно влияют на патогенетическую резистентность организма, в том числе на бактерицидную и лизоцимную активность сыворотки и фагоцитарную активность крови (37). Перед началом опыта эти показатели у всех животных имели близкие значения. Перед убоем в контрольных группах снижалась величина ЛАСК и значительно повышалась фагоцитарная активность при относительно стабильной БАСК. В группах, получавших адаптогены, показатели резистентности тоже изменялись, но они при этом существенно отличались от таковых в I и II группах. К концу заключительного откорма у свиней, получавших ПSe, на фоне снижения лизиса и содержания лизоцима в сыворотке крови повышались БАСК (с 44,76 до 54,84 \%) и ФА (с 43,3 до 48,3 \%), тогда как во II группе БАСК снизилась (с 54,29 до 52,69 \%) и при значительном повышении ФА (с 39,0 до 54,6 \%). Потребление ДКВ повышало лизис с 40,68 до 42,04 \%, содержание лизоцима - с 0,71 до 0,79 мкг/мл и БАСК с 50,48 до 52,69 \% при относительной стабильности величины ФА. Эти данные свидетельствовали о мобилизации ресурсов организма при воздействии искусственно моделируемого стресса. МС способствовал мобилизации патогенетической резистентности клеточного иммунитета, выраженной в повышении ФА $(\mathrm{p}<0,05)$, ФИ $(\mathrm{p}<0,001)$, ФЧ $(\mathrm{p}<0,05)$ у животных II контрольной группы в конце опыта. Применение адаптогенов ПSе и ДКВ приводило к нормализации этих показателей по сравнению с контролем (II группа) практически до значений без МС (ФИ при р < 0,01, ФЧ при $\mathrm{p}<0,01$ в первом и $\mathrm{p}<0,05-$ во втором случае). Таким образом, при скармливании животным адаптогенов показатели резистентности в конце опыта соответствовали таковым в I контрольной группе, что дополнительно указывает на повышение устойчивости к стрессовому воздействию (табл. 5). На этом фоне ДКВ дополнительно способствовал повышению гуморального иммунитета по сравнению с I группой $(\mathrm{p}<0,05)$. 
5. Показатели неспецифического иммунитета у свиней (Sus scrofa domesticus) $\mathrm{F}_{2}$

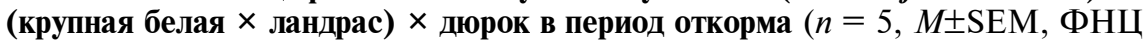
ВИЖ им. Л.К. Эрнста, 2019 год)

\begin{tabular}{|c|c|c|c|c|}
\hline \multirow{3}{*}{ Показатель } & \multicolumn{4}{|c|}{ Группа } \\
\hline & \multirow{2}{*}{ I (контрольная) } & \multicolumn{3}{|c|}{ моделируемый технологический стресс } \\
\hline & & II (контрольная) & III (ПSe) & IV (ДКВ) \\
\hline \multicolumn{5}{|c|}{ В н а ч а л е о п ы т а (перед постановкой на откорм, живая масса 35 кг) } \\
\hline Лизис, \% & $41,16 \pm 1,29$ & $40,40 \pm 0,85$ & $40,41 \pm 1,53$ & $40,68 \pm 2,00$ \\
\hline \multicolumn{5}{|l|}{ Лизоцим: } \\
\hline мкг/мл сыворотки & $0,75 \pm 0,03$ & $0,75 \pm 0,03$ & $0,72 \pm 0,03$ & $0,71 \pm 0,05$ \\
\hline уд. ед. (ед/мг белка) & $3,36 \pm 0,18$ & $3,21 \pm 0,04$ & $3,15 \pm 0,15$ & $3,08 \pm 0,13$ \\
\hline БАСК, $\%$ & $52,38 \pm 0,95$ & $54,29 \pm 1,65$ & $44,76 \pm 5,04$ & $50,48 \pm 5,30$ \\
\hline ФА, \% & $40,33 \pm 1,86$ & $39,0 \pm 2,31$ & $43,33 \pm 2,60$ & $49,67 \pm 4,67$ \\
\hline ФИ & $2,85 \pm 0,10$ & $2,72 \pm 0,05$ & $2,73 \pm 0,16$ & $2,47 \pm 0,18$ \\
\hline$\Phi Ч$ & $1,15 \pm 0,03$ & $1,06 \pm 0,08$ & $1,19 \pm 0,13$ & $1,23 \pm 0,17$ \\
\hline \multicolumn{5}{|c|}{ П е р ед у б о е м (живая масса 100 кг) } \\
\hline Лизис, \% & $22,82 \pm 2,48$ & $27,81 \pm 6,21$ & $30,10 \pm 2,86$ & $42,04 \pm 4,84^{*}$ \\
\hline \multicolumn{5}{|l|}{ Лизоцим: } \\
\hline мкг/мл сыворотки & $0,44 \pm 0,04$ & $0,52 \pm 0,09$ & $0,57 \pm 0,05$ & $0,79 \pm 0,10^{*}$ \\
\hline уд. ед. (ед/мг белка) & $2,19 \pm 0,28$ & $2,40 \pm 0,45$ & $2,56 \pm 0,17$ & $3,25 \pm 0,32$ \\
\hline БАСК, \% & $52,69 \pm 1,08$ & $52,69 \pm 1,08$ & $54,84 \pm 1,86$ & $52,69 \pm 2,15$ \\
\hline ФА, \% & $48,68 \pm 1,46$ & $54,67 \pm 2,33$ & $48,88 \pm 1,05$ & $49,89 \pm 3,62$ \\
\hline ФИ & $2,36 \pm 0,04$ & $2,92 \pm 0,04 * * *$ & $2,50 \pm 0,07^{b}$ & $2,38 \pm 0,07^{b}$ \\
\hline$\Phi Ч$ & $1,15 \pm 0,05$ & $1,60 \pm 0,08 * *$ & $1,22 \pm 0,01^{b}$ & $1,19 \pm 0,12^{\mathrm{a}}$ \\
\hline \multicolumn{5}{|c|}{$\begin{array}{l}\text { П р и м е ч а н и е. Уд. ед. - удельные единицы активности; БАСК - бактерицидная активность сыворотки } \\
\text { крови, ФА - фагоцитарная активность, ФИ - фагоцитарный индекс, ФЧ - фагоцитарное число. Описа- } \\
\text { ние групп см. в разделе «Методика». } \\
\text { *, **, *** Различия с контролем (І группа) статистически значимы соответственно при } \mathrm{p}<0,05 ; \mathrm{p}<0,01 \text { и } \\
\text { p }<0,001 . \\
\text { a, b Различия с контролем (ІІ группа) статистически значимы соответственно при } \mathrm{p}<0,05 \text { и }<<0,01 \text {. }\end{array}$} \\
\hline
\end{tabular}

6. Морфо-гематологические показатели крови у свиней (Sus scrofa domesticus) F2 (крупная белая $\times$ ландрас) $\times$ дюрок в период откорма $(n=5, M \pm S E M$, ФНЦ ВИЖ им. Л.К. Эрнста, 2019 год)

\begin{tabular}{|c|c|c|c|c|}
\hline \multirow{3}{*}{ Показатель } & \multicolumn{4}{|c|}{ Группа } \\
\hline & \multirow{2}{*}{ I (контрольная) } & \multicolumn{3}{|c|}{ моделируемый технологический стресс } \\
\hline & & II (контрольная) & III (ПSe) & IV (ДКВ) \\
\hline \multicolumn{5}{|c|}{ В н а ч а л е о п ы т а (перед постановкой на откорм, живая масса 35 кг) } \\
\hline Лейкоциты, × $10^{9} /$ л & $15,32 \pm 1,70$ & $16,12 \pm 1,28$ & $13,27 \pm 1,09$ & $14,89 \pm 2,00$ \\
\hline Эритроциты, × 1012/л & $11,30 \pm 0,17$ & $11,07 \pm 0,37$ & $11,58 \pm 0,70$ & $11,05 \pm 0,32$ \\
\hline Гемоглобин, г/л & $130,96 \pm 2,86$ & $127,00 \pm 3,00$ & $126,44 \pm 6,52$ & $131,10 \pm 3,58$ \\
\hline Гематокрит, \% & $63,02 \pm 1,14$ & $60,99 \pm 1,74$ & $61,04 \pm 3,31$ & $62,43 \pm 1,85$ \\
\hline \multirow{2}{*}{$\begin{array}{r}\text { Цветной показатель, ед. } \\
\text { П е р е д }\end{array}$} & 3,43 & 3,46 & 3,29 & 3,57 \\
\hline & з а к л юч и те льн ны & \multicolumn{2}{|c|}{ о т к о р м о м (живая масса 70 кг) } & \\
\hline Лейкоциты, $\times 10^{9} /$ л & $13,57 \pm 1,10$ & $15,27 \pm 1,01$ & $14,31 \pm 0,71$ & $14,41 \pm 0,76$ \\
\hline Эритроциты, $\times 10^{12} / л$ & $10,51 \pm 0,23$ & $10,57 \pm 0,31$ & $11,29 \pm 0,05^{* * a}$ & $10,55 \pm 0,32$ \\
\hline Гемоглобин, г/л & $133,13 \pm 3,05$ & $130,06 \pm 5,79$ & $136,12 \pm 2,72$ & $135,78 \pm 4,50$ \\
\hline Гематокрит, \% & $61,94 \pm 1,19$ & $60,23 \pm 2,73$ & $62,81 \pm 1,17$ & $62,47 \pm 2,46$ \\
\hline \multirow[t]{2}{*}{ Цветной показатель, ед. } & 3,80 & 3,71 & 3,64 & 3,87 \\
\hline & \multicolumn{2}{|c|}{ П ер ед у б о е м (живая масса $100 к г)$} & & \\
\hline Лейкоциты, × $10^{9} /$ л & $9,04 \pm 0,74$ & $11,98 \pm 1,16^{*}$ & $12,67 \pm 1,45^{*}$ & $11,01 \pm 0,78$ \\
\hline Эритроциты, × $10^{12} / л$ & $9,02 \pm 0,69$ & $9,62 \pm 0,29$ & $10,31 \pm 0,15^{\mathrm{a}}$ & $9,90 \pm 0,30$ \\
\hline Гемоглобин, г/л & $118,24 \pm 8,06$ & $121,14 \pm 2,15$ & $131,30 \pm 3,44^{\mathrm{a}}$ & $106,98 \pm 26,7$ \\
\hline Гематокрит, \% & $52,82 \pm 3,81$ & $53,91 \pm 0,88$ & $58,91 \pm 1,45^{b}$ & $57,09 \pm 1,89$ \\
\hline Цветной показатель, ед. & 3,94 & 3,78 & 3,82 & 3,24 \\
\hline \multicolumn{5}{|c|}{$\begin{array}{l}\text { П р и м е ч а н и е. Описание групп см. в разделе «Методика». } \\
\text { *, ** Различия с контролем (І группа) статистически значимы соответственно при р }<0,05 \text { и р }<0,01 \text {. } \\
\text { a, b Различия с контролем (II группа) статистически значимы соответственно при р }<0,05 \text { и p }<0,01 .\end{array}$} \\
\hline
\end{tabular}

Морфо-гематологические показатели крови в период опыта имели некоторые характерные групповые различия как по величине показателей, так и по их динамике. Так, численность лейкоцитов в период интенсивного роста в условиях MC (II, III и IV группы) была выше, чем в I группе, соответственно на 12,$5 ; 5,4$ и $6,1 \%$, при заключительном откорме - на $32,5(\mathrm{p}<0,05) ; 40,1(\mathrm{p}<0,05)$ и $21,7 \%(\mathrm{p}=0,07)$. При этом их количество снижалось во всех группах (кроме III группы, где происходило небольшое 
повышение в период интенсивного роста). Наблюдаемые изменения связаны как с действием кортизола в условиях физиологического стресса, так и с повышением неспецифической резистентности под влиянием адаптогенов (см. табл. 5). Число эритроцитов, количество гемоглобина и гематокрит у всех особей в период интенсивного роста различались мало. При этом характерным было снижение численности эритроцитов и повышение содержания гемоглобина в крови во всех группах свиней. В целом эти два показателя к завершению откорма в группах с МС были выше, чем в I, соответственно на 6,6; 14,3; 9,7\% и на 1,09; 6,09 и 4,27 (табл. 6). Следует также отметить повышение численности эритроцитов $(\mathrm{p}<0,05)$, концентрации гемоглобина $(\mathrm{p}<0,05)$ и гематокрита $(\mathrm{p}<0,01)$ в группе животных, получавших селен, по сравнению со II группой (контроль МС без адаптогенов), что свидетельствует о значимой антиокислительной роли Se в период откорма.

Таким образом, моделируемый стресс в эксперименте создавал длительный эффект, характерный для состояния дистресса. Ведущим фактором была борьба за лидерство, что приводило к перевозбуждению животных и, как следствие, к травмам, потере аппетита, перераспределению времени в системе «отдых-потребление корма», к некоторым изменениям в физиолого-биохимическом статусе. Последствия от стресса перегруппировок и перемещений могут наблюдаться в период до 15-20 сут после начала воздействия $(2,9)$. В наших исследованиях перегруппировки проводились каждые 14 сут, в течение которых животные испытывали все стадии его проявления. Однако оно было более выражено в первые 2-3 сут после перемещения. Физиолого-биохимическая оценка состояния организма свиней проводилась на 42-е сут (то есть после 3-кратного стрессового цикла) и перед убоем (на 70-е сут после двух заключительных циклов). Следует заметить, что перегруппировка, повышая двигательную активность, может оказывать и положительное влияние на формирование мышечной ткани свиней и, следовательно, на качество мяса.

Зафиксированное нами отсутствие достоверных $(\mathrm{p}<0,05)$ различий по ряду биохимических, морфо-гематологических и других показателей мы можем объяснить тем, что реализуемый уровень продуктивности свиней в опыте (в нашем случае среднесуточный прирост живой массы) был близок к генетически возможному для генотипа благодаря сбалансированному рациону и оптимальному микроклимату. В этих условиях фактором, влияющим на животных, оставался только моделируемый социальный стресс.

Отсутствие достоверной разницы и близкие с контролем концентрации кортизола, ТБК АП и ВА в сыворотке крови в целом указывают на произошедшую адаптацию организма к циклическому длительному воздействию МС. Однако те же группы различались по содержанию глюкозы, активности ЛДГ и КФК и в их динамике, что свидетельствует о лучшей стрессоустойчивости животных, получавших адаптогены в условиях моделируемого технологического стресса. Отметим, что при применении ПSе в качества адаптогена эти показатели проявления стресса оказались наивысшими, а в группе, получавшей ДКВ, - наименьшими по отношению к обеим контрольным группам. Подобные результаты были получены на бройлерах в исследованиях V. Pirgoziev с соавт. (38), которые установили, что скармливание ДКВ в разных дозах и/или при неблагоприятных условиях (например, при тепловом стрессе) может вызывать положительные реакции, в том числе повышать общий антиоксидантный статус у птицы (39).

Возможность нивелировать у свиней последствия стресса (в част- 
ности, транспортного) за счет дополнительного введения селена в рацион была изучена в работе F. Liu с соавт. (40). При скармливании животным селена (от 0,24 до 1 мг/кг) на фоне витамина Е (17-100 мг/кг) у растущих свиней наблюдали снижение гипертермии (40). Ряд других работ также посвящен влиянию селена в рационе свиней на антиоксидантный статус и качество мяса (41-43). В наших исследованиях наблюдалось положительное влияние ПSе на естественную резистентность: повышение бактерицидной активности сыворотки крови и гематологических показателей, включая рост числа эритроцитов $(\mathrm{p}<0,05)$, содержания гемоглобина $(\mathrm{p}<0,05)$ и повышение гематокрита ( $<<0,01)$ по сравнению с животными, подвергавшимися воздействию технологического стресса и не получавшими адаптогены.

Особое внимание в наших исследованиях уделялось влиянию ДКВ на биохимический, антиоксидантный и гормональный статус свиней в условиях моделируемого технологического стресса. Этот вопрос мало изучен и представлен в специальной литературе ограниченным числом публикаций. Следует упомянуть работы, в которых исследовались эффекты кверцетина, позволяющие судить о механизмах его физиологического воздействия. Так, показано, что биодоступность кверцетина обусловлена химической формой флавоноидов и диетическими факторами $(44,45)$. Основным метаболитом в плазме крови через 24 ч после поступления этой добавки в организм выступает конъюгированный кверцетин. Наибольшие концентрации кверцетина и его метаболитов выявлены в органах, ответственных за выведение продуктов метаболизма, - в печени и почках (соответственно 5,87 и 2,51 нмоль/г ткани), наименьшие - в мозге, сердце и селезенке (46). Сообщалось, что содержание кверцетина в плазме крови свиней после 3 сут потребления высоких доз (до 500 мг/кг) не превышало 1,25 ммоль/л (46, 47). Также не установлено различий при длительном и многократном применении в сравнении с однократным (48). Из диетических факторов на биодоступность кверцетина влияло содержание жира в рационе (45). Установлено, что сочетание витамина Е с кверцетином приводит к лучшему положительному эффекту (49). Кверцетин не влиял на активность глутатионпероксидазы, глутатионредуктазы и глутаматцистеин-лигазы в слизистой тонкого кишечника и печени поросят после отъема, при этом активность печеночной глутатионтрансферазы значительно увеличивалась на 5-е сут после отъема при приеме кверцетина в дозах 100, 300 и 900 мг/кг живой массы (50). Кверцетин усиливал защиту эритроцитов кишечника свиней от окислительного стресса (51). Установлено, что при контаминации кормов микотоксинами кверцетин (самостоятельно или в комбинации с витаминами и селеном) способствовал частичному восстановлению оксидативного статуса животных (52), что корреспондируется с полученными и вышеописанными нами данными. У свиней кверцетин снижал степень воздействия транспортного стресса через уменьшение количества сывороточного эндотоксина, АФК и малонового диальдегида в кишечнике, увеличение размера ворсинок тощей кишки с одновременное снижением экспрессии в ней воспалительных цитокинов (53). При этом отмечали повышение адаптивных возможностей организма животных под влиянием антиоксиданта при воздействии технологического стресса, что также согласуется с результатами наших исследований.

Итак, включение в рацион свиней адаптогенов протеината $\mathrm{Se}(\Pi \mathrm{Se})$ и в особенности дигидрокверцетина (ДКВ) в условиях моделируемого технологического стресса (МС) профилактировало его отрицательное действие на метаболические процессы, включая перекисное окисление липидов, стимулировало анаболические процессы, положительно повлияло на клини- 
ческое здоровье и неспецифическую резистентность животных. Наименьшее количество кортизола - гормона, участвующего в развитии стрессовых реакций (134 нмоль/л в период интенсивного роста и 215 нмоль/л при заключительном откорме), отмечали у свиней в группе с ДКВ, наибольше в группе с ПSе в период интенсивного роста (282 против 211 и 214 нмоль/л в контрольных группах). Количество активных продуктов тиобарбитуровой кислоты, характеризующее состояние системы перекисного окисления липидов, было наименьшим (2,93 нмоль/л) в группе с ДКВ в период интенсивного роста и наибольшее $(3,47$ нмоль/л) - в той же группе в период заключительного откорма. У свиней, получавших ДКВ, отмечено повышение гуморального иммунитета, что проявлялось в росте количества лизоцима (на 51,9 \%, р < 0,05) и усилении лизиса (на 19,22\%, p < 0,05) по сравнению с I группой (контроль без МС). В результате в разные периоды исследования среднесуточный прирост живой массы свиней составил 9211103 г в группе с ПSе и 950-1152 г в группе с ДКВ. В целом за опыт средний прирост был наибольшим в контроле (без стресса) и в группе, где на фоне МС животным скармливали ДКВ. В совокупности полученные данные указывают на перспективность применения ПSе и ДКВ в интенсивном свиноводстве для возможного нивелирования отрицательных последствий технологических стрессов и необходимость продолжить изучение механизмов действия этих кормовых адаптогенов.

\section{ЛИТЕРАТУРА}

1. Смирнов А.М., Шабунин С.В., Рецкий М.И., Донник И.М., Скира В.Н., Суворов А.В., Бабышова Л.В. Новые методы исследования по проблемам ветеринарной медицины. Ч. ІІІ. M., 2007.

2. Плященко С.И., Сидоров В.Т. Предупреждение стрессов у сельскохозяйственных животных. Минск, 1983.

3. Selye H. A syndrome produced by diverse nocuous agents. Nature, 1936, 138: 32.

4. Martinez-Miro S., Tecles F., Ramon M., Escribano D., Hernandez F., Madrid J., Orengo J., Martinez-Subiela S., Manteca X., Ceron J.J. Causes, consequences and biomarkers of stress in swine: an update. BMC Veterinary Research, 2016, 12(1): 171 (doi: 10.1186/s12917-016-0791-8).

5. Zupan M., Zanella A.J. Peripheral regulation of stress and fear responses in pigs from tail-biting pens. Revista brasileira de zootecnia-brazilian journal of animal science, 2017, 46: $33-38$ (doi: 10.1590/S1806-92902017000100006).

6. Coutellier L., Arnould C., Boissy A., Orgeur P., Prunier A., Veissier I., Meunier-Salaün M.C. Pig's responses to repeated social regrouping and relocation during the growing-finishing period. Applied Animal Behavior Science, 2007, 105: 102-115 (doi: 10.1016/j.applanim.2006.05.007).

7. Remience V., Wavreille J., Canart B., Meunier-Salau M.C., Prunier A., Bartiaux-Thill N., Nicks B., Vandenheede M. Effects of space allowance on the welfare of dry sows kept in dynamic groups and fed with an electronic sow feeder. Applied Animal Behavior Science, 2008, 112: 284296 (doi: 10.1016/j.applanim.2007.07.00).

8. Verdon M., Hansen C.F., Rault J.L., Jongman E., Hansen L.U., Plush K., Hemsworth P.H. Effects of group housing on sow welfare: a review. Journal of animal science, 2015, 93: 1999-2017 (doi: 10.2527/jas.2014-8742).

9. Pereira T.L., Corassa A., Komiyama C.M., Araújo C.V., Kataoka A. The effect of transport density and gender on stress indicators and carcass and meat quality in pigs. Spanish Journal of Agricultural Research, 2015, 13(3): 11 (doi: 10.5424/sjar/2015133-6638).

10. Zupan M., Zanella A.J. Peripheral regulation of stress and fear responses in pigs from tail-biting pens. Revista brasileira de zootecnia-brazilian journal of animal science, 2017, 46: $33-38$ (doi: 10.1590/S1806-92902017000100006).

11. Holinger M., Fruh B., Stoll P., Graage R., Wirth S., Bruckmaier R., Prunier A., Kreuzer M., Hillmann E. Chronic intermittent stress exposure and access to grass silage interact differently in their effect on behaviour, gastric health and stress physiology of entire or castrated male growingfinishing pigs. Physiology \& Behavior, 2018, 195: 58-68 (doi: 10.1016/j.physbeh.2018.07.019).

12. Данилевская Н.В., Тухфатова Н.Ф. Использование метода селективной деконтаминации при отъеме поросят. Аграрный вестник Урала, 2012, 5: 36-39. 
13. Minotti G., Aust S.D. The role of iron in oxygen radical mediated lipid peroxidation. ChemicoBiological Interactions, 1989, 71(1): 1-19.

14. Толкушкина Г.Д. Система антиоксидантной защиты животных при хронических антропогенных нагрузках: теоретические предпосылки. В сб.: Сельское хозяйство Сибири на рубеже веков: итоги и перспективы развития. Новосибирск, 2001: 136-137.

15. Carpenter R., O’Grady M.N., O’Callaghan Y.C., O’Brien N.M., Kerry J.P. Evaluation of the antioxidant potential of grape seed and bearberry extracts in raw and cooked pork. Meat Science, 2007, 76(4): 604-610 (doi: 10.1016/j.meatsci.2007.01.021).

16. Habanova M., Haban M. Evaluation of antiradical activity of chosen plant resources. Acta Fytotechnica et Zootechnica, 2008, 1: 21-24.

17. Sekretar S., Schmidt S., Vajdak M., Zahradnikova L. \& Annus J. Antioxidative and antimicrobial effects of some natural extracts in lard. Czech Journal of Food Sciences, 2018, 22: 215-218 (doi: 10.17221/10664-CJFS)

18. Shaposhnikov M.V., Shilova L.A., Plyusnina E.N., Volodina S.O., Volodin V.V., Moskalev A.A. Influence of preparations containing phytoecdysteroids and plant steroid glycosides on the life span and stress resistance of Drosophila melanogaster. Russian Journal of Genetics: Applied Research, 2016, 6(2): 215-222 (doi: 10.1134/S2079059716020106).

19. Плотников М.Б., Тюкавкина Н.А., Плотникова Т.М. Лекарственные препараты на основе диквертина. Томск, 2005.

20. Costa L.G., Garrick J.M., Roquè P.J., Pellacani C. Mechanisms of neuroprotection by quercetin: counteracting oxidative stress and more. Oxidative Medicine and Cellular Longevity, 2016, 2016: 2986796 (doi: 10.1155/2016/2986796).

21. Фомичев Ю.П., Никанова Л.А., Дорожкин В.И., Торшков А.А., Романенко А.А., Еськов Е.К., Семенова А.А., Гоноцкий В.А., Дунаев А.В., Ярошевич Г.С., Лашин С.А., Стольная Н.И. Дигидрокверцетин и арабиногалактан - природные биорегуляторы в жизнедеятельности человека и животных, применение в сельском хозяйстве и пищевой промышленности. М., 2017.

22. Никанова Л.А., Фомичев Ю.П. Роль кормовых добавок в ослаблении экологического температурного стресса у свиней. Российский журнал. Проблемы ветеринарной санитарии, гигиены и экологии, 2012, 1(7): 62-65.

23. Zou Y., Wei H. K., Xiang Q.-H., Wang J., Zhou Y.-F., Peng J. Protective effect of quercetin on pig intestinal integrity after transport stress is associated with regulation oxidative status and inflammation. Journal of Veterinary Medical Science, 2016, 78(9): 1487-1494 (doi: 10.1292/jvms. 16-0090).

24. Knyazev V.V., Rogovskii V.S., Sveshnikova E.D., Semeikin A.V., Matyushin A.I., Fedotcheva T.A., Shimanovski, N.L., Pozdeev A.O., Koroteev A.M., Koroteev M.P. Synthesis and antioxidant and cytotoxic activity of new dihydroquercetin derivatives. Pharmaceutical Chemistry Journal, 2018, 52(3): 205-208 (doi: 10.1007/s11094-018-1788-3).

25. Некрасов Р.В., Головин А.В., Махаев Е.А., Аникин А.С., Первов Н.Г., Стрекозов Н.И., Мысик А.Т., Дуборезов В.М., Чабаев М.Г., Фомичев Ю.П., Гусев И.В. Нормы потребностей молочного скота и свиней в питательных веществах /Под ред. Р.В. Некрасова, А.В. Головина, Е.А. Махаева. М., 2018.

26. Зайцев С.Ю., Конопатов Ю.В. Биохимия животных. Фундаментальные и клинические аспекты. СПб, 2004.

27. Schiller K.R., Mauro L.J. Tyrosine phosphatases as regulators of skeletal development and metabolism. Journal of Cellular Biochemistry, 2005, 96(2): 262-277 (doi: 10.1002/jcb.20515).

28. Kolp E., Wilkens M.R., Pendl W., Eichenberger B., Liesegang A. Vitamin D metabolism in growing pigs: influence of UVB irradiation and dietary vitamin D supply on calcium homeostasis, its regulation and bone metabolism. Journal of Animal Physiology and Animal Nutrition, 2017, 101: 79-94 (doi: 10.1111/jpn.12707).

29. Ayala I., Martos N.F., Silvan G., Gutierrez-Panizo C., Clavel J.G., Illera J.C. Cortisol, adrenocorticotropic hormone, serotonin, adrenaline and noradrenaline serum concentrations in relation to disease and stress in the horse. Research in Veterinary Science, 2012, 93(1): 103-107 (doi: 10.1016/j.rvsc.2011.05.013).

30. Hart K.A. The use of cortisol for the objective assessment of stress in animals: pros and cons. The Veterinary Journal, 2012, 192(2): 137-139 (doi: 10.1016/j.tvj1.2012.03.016).

31. Aldini G., Yeum K.-J., Niki E., Russell R.M. Biomarkers for antioxidant defense and oxidative damage: principles and practical applications. Blackwell Publishing Ltd., 2010.

32. Dvořák Z. Creatine as an indicator of net muscle proteins. Journal of the Science of Food and Agriculture, 1981, 32(10): 1033-1036 (doi: 10.1002/jsfa.2740321013).

33. Mondal S., Raja K., Schweizer U., Mugesh G. Chemistry and biology in the biosynthesis and action of thyroid hormones. Angewandte Chemie International Edition, 2016, 55(27): 7606-7630 (doi: 10.1002/anie.201601116). 
34. Kyrou I., Chrousos G.P., Tsigos C. Stress, visceral obesity, and metabolic complications. Annals of the New York Academy of Sciences, 2006, 1083(1): 77-110 (doi: 10.1196/annals. 1367.008).

35. Russell K.E., Roussel A.J. Evaluation of the ruminant serum chemistry profile. Veterinary Clinics of North America: Food Animal Practice, 2007, 23(3): 403-426 (doi: 10.1016/j.cvfa.2007.07.003).

36. Тамбовцева Р.В. Биохимические особенности онтогенетического развития энергообеспечения мышечной деятельности. Новые исследования, 2014, 1(38): 68-75.

37. Плященко С.И., Сидоров В.Г. Естественная резистентность организма животных. Л., 1979.

38. Pirgozliev V., Westbrook C., Woods S., Karageçili M., Karadas F., Rose S.P., Mansbridge S. Feeding dihydroquercetin to broiler chickens. British Poultry Science, 2018, 60(3): 241-245 (doi: 10.1080/00071668.2018.1556387).

39. Pirgozliev V., Westbrook C., Woods S., Mansbridge S., Rose S., Whiting I., Yovchev D., Atanasov A., Kljak K., Staykova G., Ivanova S., Karagecili M., Karadas F., Stringhini J.H. Feeding dihydroquercetin and vitamin $\mathrm{E}$ to broiler chickens reared at standard and high ambient temperatures. Preprint. bioRxiv, 2020.05.19.104398 (doi: 10.1101/2020.05.19.104398).

40. Liu F., Cottrell J., Leury B.J., Chauhan S., Celi P., Abrasaldo A., Dunshea F.R Selenium or vitamin e mitigates hyperthermia in growing pigs. Journal of Nutrition \& Intermediary Metabolism, 2014, 1: 22 (doi: 10.1016/j.jnim.2014.10.073).

41. Jiang J., Tang X., Xue Y., Lin G., Xiong Y.L. Dietary linseed oil supplemented with organic selenium improved the fatty acid nutritional profile, muscular selenium deposition, water retention, and tenderness of fresh pork. Meat Science, 2017, 131: 99-106 (doi: 10.1016/j.meatsci.2017.03.014).

42. Chen J., Tian M., Guan W., Wen T., Chen F., Zhang S., Song J., Ren C., Zhang Y., Song. H. Increasing selenium supplementation to a moderately-reduced energy and protein diet improves antioxidant status and meat quality without affecting growth performance in finishing pigs. Journal of Trace Elements in Medicine and Biology, 2019, 56: 38-45 (doi: 10.1016/j.jtemb.2019.07.004).

43. Son A.R., Jeong J.Y., Park K.R., Kim M., Lee S.D., Yoo J.H., Do Y.J., Reddy K.E., Lee H.J. Effects of graded concentrations of supplemental selenium on selenium concentrations in tissues and prediction equations for estimating dietary selenium intake in pigs. PeerJ, 2018, 6: e5791 (doi: 10.7717/peerj.5791).

44. Cermak R., Landgraf S., Wolffram S. The bioavailability of quercetin in pigs depends on the lycoside moiety and on dietary factors. The Journal of Nutrition, 2003, 133 (9): 2802-2807 (doi: $10.1093 / \mathrm{jn} / 133.9 .2802)$.

45. Lesser S., Cermac R., Wolffram S. Bioavaibilty of quercetin in pigs is influenced by the dietary fat content. The Journal of Nutrition, 2004, 134(6): 508-1511 (doi: 10.1093/jn/134.6.1508).

46. De Boer V.C.J., Dihal A.A., Boer H., van der Woude, Arts I.C.W., Wolffram S., Alink G.M., Rietjens I.M.C.M., Keijer J., Hollman P.C.H. Tissue distribution of quercetin in rats and pigs. The Journal of Nutrition, 2005, 135(7): 1718-1725 (doi 10.1093/jn/135.7.1718).

47. Percival S.S. Commentary on: tissue distribution of quercetin in rats and pigs. The Journal of Nutrition, 2005, 135: 1617-1618 (doi: 10.1093/jn/135.7.1617).

48. Bieger J., Cermak R., Blank R., de Boer V.C.J., Hollman P.C.H., Kamphues J., Wolffram S. Tissue distribution of quercetin in pigs after long-term dietary supplementation. The Journal of Nutrition, 2008, 138(8): 1417-1420 (doi: 10.1093/jn/138.8.1417).

49. Luehring M., Blank R., Wolffram S. Vitamin E-sparing and vitamin E-independent antioxidative effects of the flavonol quercetin in growing pigs. Animal Feed Science and Technology, 2011, 169: 199-207 (doi: 10.1016/j.anifeedsci.2011.06.006).

50. Ma Z. The effect of dietary quercetin on glutathione kinetics in the gut mucosa of weaned piglets. Master's dissertation. Gent University, 2016. Режим доступа: https://lib.ugent.be/en/cata$\log / \operatorname{rug} 01: 002305194$. Дата обращения: 15.09.2019.

51. Chen F., Yuan Q., Xu G., Chen H., Lei H., Su I. Effects of quercetin on proliferation and $\mathrm{H}_{2} \mathrm{O}_{2}-$ induced apoptosis of intestinal porcine enterocyte cells. Molecules, 2018, 23: 2012 (doi: 10.3390/molecules23082012).

52. Thanh B.V.L., Lemay M., Bastien A., Lapointe J., Lessard M., Chorfi G., Guay F. The potential effects of antioxidant feed additives in mitigating the adverse effects of corn naturally contaminated with Fusarium mycotoxins on antioxidant systems in the intestinal mucosa, plasma, and liver in weaned pigs. Mycotoxin Research, 2016, 32(2): 99-116 (doi: 10.1007/s12550-016-0245-y).

53. Zou Y., Xiang Q., Wang J., Wei H., Peng J. Effects of oregano essential oil or quercetin supplementation on bodyweight loss, carcass characteristics, meat quality and antioxidant status in finishing pigs under transport stress. Livestock Science, 2016, 192: 33-38 (doi: 10.1016/j.livsci.2016.08.005).

\section{1 ФГБНУ Федеральный научный иентр} животноводства - ВИЖ им. академика Л.К. Эрнста, 142132 Россия, Московская обл., г.о. Подольск, пос. Дубровицы, 60, e-mail: urij.fomichev@yandex.ru,nek_roman@mail.ru $₫, 652202 @$ mail.ru, chabaev.m.g-1@mail.ru,brukw@bk.ru;
Поступила в редакцию 5 февраля 2020 года 


\title{
PHYSIOLOGICAL AND BIOCHEMICAL EFFECTS OF TWO FEED ANTIOXIDANTS IN MODELING TECHNOLOGICAL STRESS IN PIGS ( Sus scrofa domesticus Erxleben, 1777)
}

\author{
Yu.P. Fomichev', N.V. Bogolyuboval, R.V. Nekrasov', M.G. Chabaev', R.A. Rykov'1, \\ A.A. Semenova ${ }^{2}$
}

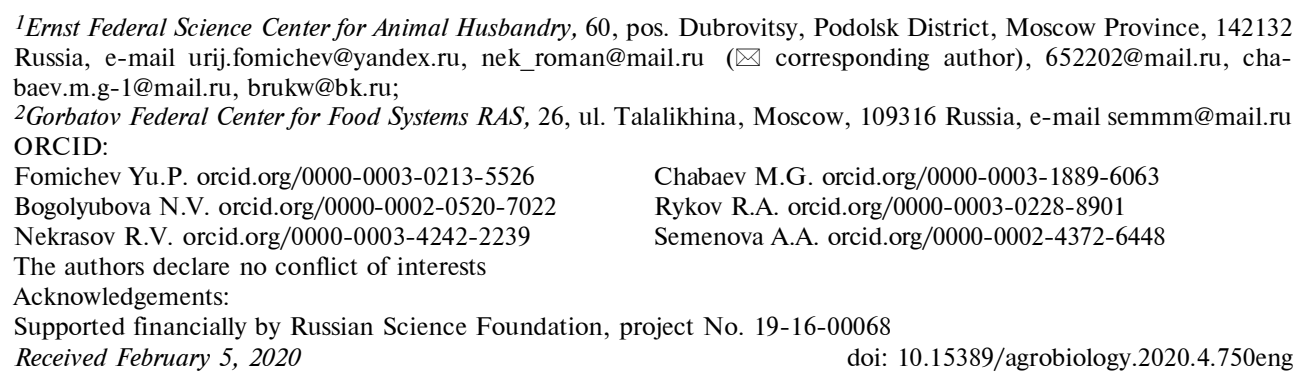

\section{Abstract}

Intensive livestock technologies do not fit well with the physiology of domestic species and put farm animals at risk of various health problems and disorders, which most negatively affects highly productive animals with intensive metabolism. Feed antioxidants might be a solution to improve productive health, adaptive capabilities and stress resistance of livestock. The outcome of adaptogen application depends on thorough elucidation of mechanisms of their action on physiological and biochemical processes in the body compromised by stress. Our study imitated social stress (modeled stress, MS) as the most common in intensive livestock to compare two dietary antioxidant additives of different origin and chemical composition. Thirty-six hybrid boars F2 (Large White $\times$ Landrace) $\times$ Duroc aged 103 days (35 kg live weight) were assigned for four treatments ( 9 animals per each): $1-$ control without MS, 2 - control with MS, 3 - MS + proteinate Se (PSe) (B-TRAXIM Selenium-11, PANCOSMA CANADA, Inc.; $0.2 \mathrm{mg}$ a.i. per $1 \mathrm{~kg}$ feed), and $4-\mathrm{MS}+$ dihydroquercetin (DHQ) Ekostimul-2 drug (OOO Ametic, Russia; $32 \mathrm{mg}$ a.i. per $1 \mathrm{~kg}$ feed). To simulate social stress, boars were moved every 14 days within the group to change the neighbors. Blood for assay was sampled three times over the trial from five boars of each group. With age, the blood cortisol level was revealed first to decrease by 36.8. 22.5, 41.3 and $52.8 \%$ from the initial values in groups $1,2,3$ and 4 , respectively, though by the end of the final feeding there was a $46.4 ; 37.4 ; 8.1$ and $60.4 \%$ increase in the parameter. The cortisol concentration was the highest in group 3 (MS + PSe) during intensive growth (282 nmol/1 vs. 211 and $214 \mathrm{nmol} / 1$ for groups 1 and 2). In groups 1, 2 (MS), and 3 (MS + PSe), the cortisol concentration reached 309, 294 and $305 \mathrm{nmol} / \mathrm{l}$ by the end of feeding. Blood cortisol level was the lowest in group $4(+\mathrm{DHQ}), 134 \mathrm{nmol} / \mathrm{l}(\mathrm{p}=0.07$ compared to group 2$)$ at intensive growth and $215 \mathrm{nmol} / \mathrm{l}$ at final fattening, corresponding with TBK AP levels which were also 6.7 and $12.3 \%$ lower, respectively. Lactate dehydrogenase (LDH) activity and creatine phosphokinase (CPK) activity also altered. In group 1, LDH activity decreased from 459.4 to 377.5 IU/1 over the trial. The same pattern was characteristic of group 4 (MS + DHQ). In group 2 (MS) and group 3 (MS + PSe), LDH activity declined to 317.0 and $289.3 \mathrm{IU} / 1$ by the end of feeding, which was $16.0(\mathrm{p}<0.01)$ and $23.4 \%$ $(\mathrm{p}<0.01)$ less than in group 1 . In group 4 , the index, being constantly decreasing over the trial as in group 1, remained 15.0, 7.0 ( $\mathrm{p}=0.06$ compared to control group 2 with MS) and $2.7 \%$ lower than in groups 1, 2 and 3. The MS lowered the blood glucose concentration by $13.8 \%(\mathrm{p}<0.05)$ compared to control 1 during the final fattening period. In group 3, this indicator as influenced by MS was also $7.4 \%$ lower $(\mathrm{p}<0.05)$, but due to PSe, a $7.4 \%$ increase occurred compared to control group 2. Dietary DHQ led to the leveling of negative effects of MS, which, together with low cortisol indices in this group, stabilized the blood glucose concentration at the control level without MS in group 1. The DHQ was found to also contribute to a $25 \%(\mathrm{p}<0.01)$ increase in blood triglycerides during final fattening compared to group 1 without stress. Pigs also differed in pathogenetic resistance. MS mobilized the cellular immunity through an increase in phagocytic activity PA $(\mathrm{p}<0.05)$, phagocytic index PI $(\mathrm{p}<0.001)$, and phagocytic number PN $(\mathrm{p}<0.05)$ in control group 2 at the end of the test. PSe and DHQ normalized these indicators compared to control (group 2) practically to the control values without MS ( $p<0.01$ for PI; $p<0.01$ and $p<0.05$ for PN, respectively). Thus, in 
animals fed adaptogens, the resistance indices at the end of the experiment corresponded to those in the control group 1, which indicates higher stress resistance, and DHQ additionally promoted humoral immunity as compared to the control group $1(\mathrm{p}<0.05)$, which confirms the ability the adaptogens to enhance the body resistance to stress. Interestingly, despite the absence of statistically significant differences between most of the studied biochemical parameters $(p>0.05)$ which indicate a balanced animal diet, changes were noted that characterize the effect of the adaptogens under MS. In groups $2-4$, blood phosphorus concentration was higher than in control group $1,4.42(\mathrm{p}=0.07), 4.52(\mathrm{p}=0.1)$ and $4.64 \mathrm{mmol} / \mathrm{l}(\mathrm{p}<0.05)$ vs. $3.94 \mathrm{mmol} / \mathrm{l}$. Thereof, the $\mathrm{Ca} / \mathrm{P}$ ratio changed significantly during fattening. In group 2 (MS), group 3 (MS + PSe) and group 4 (MS + DHQ), the values $1.01(\mathrm{p}<0.05)$, $0.99(\mathrm{p}<0.05)$ and $0.89(\mathrm{p}<0.001)$ vs. 1.15 in group 1 without stress. Blood morphology in pigs also changed as influenced by MS and the adaptogens. The counts of blood leukocytes in groups 2 , 3 and 4 was $12.5 ; 5.4$ and $6.1 \%$ higher than in group 1 in the middle of fattening period, and 32.5 $(\mathrm{p}<0.05), 40.1(\mathrm{p}<0.05)$ and $21.7 \%(\mathrm{p}=0.07)$ higher at the final fattening. A decrease in the number of erythrocytes and an increase in the hemoglobin amount in blood were characteristic of all groups. In general, by the end of feeding animals subjected to MS these two indicators were 6.6, 14.3, $9.7 \%$ and $1.09,6.09,4.27 \%$ higher than in group 1 . An increase in blood erythrocytes $(\mathrm{p}<0.05)$, hemoglobin $(\mathrm{p}<0.05)$ and hematocrit $(\mathrm{p}<0.01)$ in animals fed selenium vs. control group 2 indicates a decisive role of Se adaptogen as antioxidant during fattening. The observed changes were associated both with the action of cortisol generated by physiological stress, and with an increase in nonspecific resistance of boars due to the adaptogens. Importantly, the average daily weight gain in boars was close to that genetically conditioned for the genotype F2 (Large White $\times$ Landrace) $\times$ Duroc. As a result, over the entire period of the trial, groups 1, 2, 3, and 4 showed an average increase of 1047, 1035, 1003 and $1042 \mathrm{~g}$, respectively, of which the weight gain was the greatest in control 1 (without stress) and in group 4 fed DHQ at MS. Thus, our findings give grounds for further studying effects of these feed adaptogens for their proper use in intensive industrial pig breeding.

Keywords: stress, pigs, adaptogens, antioxidants, dihydroquercetin, selenium, cortisol, lactate dehydrogenase, hematological indicators, creatine phosphokinase, TBA-active products, nonspecific resistance. 